\title{
Problems and Constraints in the Production and Marketing of Carnation Cut Flowers in Himachal Pradesh
}

\author{
Preeti Sharma*, H. S. Baweja, K. K. Raina, B. S. Dilta, Y. C. Gupta and Pardeep Kumar \\ Department of Floriculture and Landscape Architecture, College of Horticulture, Dr Y S \\ Parmar University of Horticulture and Forestry, Nauni, Solan (H P), India \\ *Corresponding author
}

Keywords

Carnation Cut

Flowers,

Floriculture

Article Info

Accepted:

26 October 2020

Available Online:

10 November 2020

\section{A B S T R A C T}

Floriculture is gaining an emerging business in India and has attained popularity among the stake holders which is evident from the data w.r.t area and production during the last fifteen years. During 2018-19 total area under floriculture in India was 313 thousand ha and in Himachal Pradesh it was 629.29 ha (NHB, 2019). The Govt. of India as well as HP has launched a large number of schemes to promote protected cultivation of various flower crops including carnation. So much so, a lot of research work has been carried out to improve the yield and quality of carnation cut flowers. In spite of all these, the stake holders are experiencing several constraints with respect to production of quality cut flowers in huge quantum including their marketing. Hence, the present study was conducted to ascertain the specific problems and constraints faced by the growers in producing better quality cut flowers, their marketing and obtaining higher $\mathrm{B}: \mathrm{C}$ ratio in ten districts of Himachal Pradesh. So, from the present study it can be concluded that the selected carnation growers are experiencing problems regarding infrastructure facilities, high cost of inputs, incidence of disease \& insect-pest, finances and market knowledge.

\section{Introduction}

Flower production is considered as a profitable business enterprise and is regarded as a means of socio-economic development in India. The economic importance of floriculture was not considered and it was not practiced commercially but in present times, it has emerged as a profitable venture. The country has tremendous potential when it comes to expanding the floriculture as a profitable business and possesses certain advantages over other flower growing countries like congenial climatic conditions, cheap labour, huge market base and support from the Central and state Govt. Development of advanced technologies in raising ease the life of human beings In spite of all these, the stake holders are experiencing several constraints with respect to production of quality cut flowers in huge quantum including their marketing. Several schemes have been started by the National as well as the State Govt. to promote the commercial flower production among different categories of farmers in the state. In spite of all the assistance provided by the Govt., growers are experiencing certain problems in production 
and marketing of flowers. Present study has been conducted in order to get acquainted with these problems and constraints in the ten carnation growers' districts of Himachal Pradesh.

\section{Materials and Methods}

The study was conducted in ten carnation growing districts of Himachal Pradesh (except Kinnaur and Lahual Spiti) as these are not suitable for carnation cultivation and nobody is practicing commercial cultivation of carnation in these two districts. A list of all the carnation growers from ten districts was procured and farmers were selected using proportional allocation method. Then farmers were further divided in to seven categories based upon the area under carnation cultivation. Secondary data was collected from Dept of Horticulture HP and from different published and unpublished sources. For the collection of primary data a set of pretested questionnaires was prepared and information was gathered by personal interviews or by telecommunication. Opinion survey was conducted using Five point Likert scale to know the attitude of the respondents for one particular problem. It is an ordinal psychometric measurement of attitudes, beliefs and opinions. For each statement a respondent must indicate a degree of agreement and disagreement. Data then gathered was analyzed using mean, percentage, frequency and ranking was done using weighted score technique.

\section{Results and Discussion}

\section{Socio-economic profile of respondents}

Table 1 represents the data regarding socioeconomic profile of the respondent carnation growers. Perusal of data reveals that majority $(60.48 \%)$ of the respondents belong to middle age group followed by 29.03 per cent respondents belonging to old age group, only 10.49 per cent of the respondents were in the age group of 20-30 years. The data depicts that age is not a major factor and people from all age groups are involved in business..

Education is an important factor that influences the behaviour of the grower and helps in acquiring the newly developed technologies. Therefore education level of respondents was also studied and data reveals that only 4.84 per cent respondents were illiterate and majority of them are educated up to high school (40.32\%), followed by respondents educated up to secondary (29.84\%) while 25 per cent of the respondents had an education up to graduation and above. Experience enhances the skills of a person therefore farming experience of respondents was studied and it was found that majority of the respondents $(33.87 \%)$ were having an experience of 5-10 years in carnation cultivation. To acquire any advanced technology financial soundness ot he respondent is necessary and data concerning annual income of the respondents reveals that majority of the respondents $(35.48 \%)$ have an annual income of Rs 50,000- 1,00,000 and most of them (37.90\%) were earning $30-50 \%$ share of their total income from carnation cultivation. Regarding financial assistance, there is no significant difference in various financial sources used by the respondents.

\section{Problems experienced by carnation growers}

Data pertaining to problems faced by the respondent carnation growers is presented in Table 2. Problems were categorized in to four broad categories i.e. problems related to production of carnation, financial problems, problems regarding packing \& transportation and problems related to marketing of carnation. 


\section{Production related problems}

Perusal of data reveals that inadequate infrastructure facility with a mean score of 98.00 was the major problem encountered by most of the respondents and therefore assigned first rank. High input cost was the other major problem in commercial cultivation of carnation with a mean score of 94.4 and ranked second by the respondents, followed by loss due to infestation of disease and pest with a mean score of 94.00 (III rank), lack of skilled labour (rank IV and mean score 90.20 ), unavailability of quality planting material (rank V and mean score 87.12) and lack of quality irrigation water with the least mean score (84.00) and thus, ranked sixth.
Problems related to finances of respondents

Floriculture is a capital intensive business and requires huge investment. In spite of the financial assistance provided by the Govt., farmers were facing certain monetary issues and were enumerated in Table 2. Inspection of data reveals that partial and delayed payments from sellers end was ranked first with a mean score of 94.6, followed by the insufficient amount of money at the time of requirement (rank $\mathrm{II}^{\text {nd }}$ with a mean score of 93.00) and high interest rate on loans with a mean score of 84.00 and therefore, assigned third rank. The results are in accordance with the findings of Raina et al., (2017) and Ghadge et al., (2010).

Table.1 Socio-economic profile of respondent carnation growers

\begin{tabular}{|c|c|c|c|}
\hline $\begin{array}{l}\text { Profile } \\
\text { characters }\end{array}$ & Category & Frequency & Percentage \\
\hline \multirow[t]{3}{*}{ Age } & 20-30 (Young) & 13 & 10.49 \\
\hline & 30-50 (Middle age) & 75 & 60.48 \\
\hline & $\geq 50($ Old age $)$ & 36 & 29.03 \\
\hline \multirow[t]{4}{*}{ Education } & Illiterate & 6 & 4.84 \\
\hline & Primary- High School & 50 & 40.32 \\
\hline & Secondary & 37 & 29.84 \\
\hline & Graduate \& above & 31 & 25.00 \\
\hline \multirow{4}{*}{$\begin{array}{l}\text { Farming } \\
\text { Experience }\end{array}$} & $\leq 3$ years & 19 & 15.32 \\
\hline & 3-5 years & 32 & 25.81 \\
\hline & 5-10 years & 42 & 33.87 \\
\hline & $\geq 10$ years & 31 & 25.00 \\
\hline \multirow{4}{*}{$\begin{array}{l}\text { Annual } \\
\text { income }\end{array}$} & $\leq 25,000$ & 17 & 13.70 \\
\hline & $25,000-50,000$ & 42 & 33.88 \\
\hline & $50,000-1,00,000$ & 44 & 35.48 \\
\hline & $\geq 1,00,000$ & 21 & 16.94 \\
\hline \multirow{4}{*}{$\begin{array}{l}\text { Share of } \\
\text { carnation } \\
\text { cultivation } \\
\text { in income }\end{array}$} & $<10 \%$ & 22 & 17.75 \\
\hline & $10-30 \%$ & 42 & 33.87 \\
\hline & $30-50 \%$ & 47 & 37.90 \\
\hline & $>50 \%$ & 13 & 10.48 \\
\hline \multirow{5}{*}{$\begin{array}{l}\text { Major } \\
\text { source of } \\
\text { financing }\end{array}$} & Own & 40 & 32.26 \\
\hline & Bank & 39 & 31.45 \\
\hline & Co-operative societies & 38 & 30.65 \\
\hline & Others & 7 & 5.64 \\
\hline & Total & 124 & 100.00 \\
\hline
\end{tabular}


Table.2 Problems and constraints experienced in production and marketing of carnation

\begin{tabular}{|c|c|c|c|c|c|c|c|c|}
\hline S.No & Problems & Frequency & Percentage & $\begin{array}{l}\text { Weighted } \\
\text { score }\end{array}$ & Mean & $\begin{array}{l}\text { Standard } \\
\text { deviation }\end{array}$ & Skewness & Rank \\
\hline $\mathbf{A}$ & \multicolumn{3}{|c|}{ Problems regarding cultivation of carnation } & & & & & \\
\hline 1 & Quality planting material & 76 & 61.29 & 436 & 87.2 & 75.91 & 0.46 & $\mathrm{~V}$ \\
\hline 2 & $\begin{array}{l}\text { Inadequate infrastructure } \\
\text { facilities }\end{array}$ & 99 & 79.84 & 490 & 98.0 & 112.67 & 0.61 & I \\
\hline 3 & High cost of inputs & 90 & 72.58 & 472 & 94.4 & 98.61 & 0.62 & II \\
\hline 4 & $\begin{array}{l}\text { Unavailability of skilled } \\
\text { labour }\end{array}$ & 84 & 67.74 & 451 & 90.2 & 91.18 & 0.57 & IV \\
\hline 5 & Irrigation facilities & 72 & 58.06 & 420 & 84.0 & 71.42 & 0.54 & VI \\
\hline 6 & Disease infestation & 90 & 72.58 & 470 & 94.0 & 98.19 & 0.60 & III \\
\hline B & \multicolumn{3}{|l|}{ Financial problems } & & & & & \\
\hline 1 & Insufficient credit & 86 & 69.35 & 465 & 93 & 96.86 & 0.85 & II \\
\hline 2 & $\begin{array}{l}\text { High interest rate on } \\
\text { Loans }\end{array}$ & 70 & 56.45 & 420 & 84 & 66.57 & 0.43 & III \\
\hline 3 & $\begin{array}{l}\text { Amount and timely } \\
\text { payment of money }\end{array}$ & 93 & 75.00 & 473 & 94.6 & 102.43 & 0.58 & I \\
\hline $\mathbf{C}$ & \multicolumn{7}{|c|}{ Problems related to storage, packing and transportation } & \\
\hline 1 & $\begin{array}{l}\text { Perishable nature of } \\
\text { produce }\end{array}$ & 91 & 73.39 & 483 & 96.6 & 103.30 & 0.80 & I \\
\hline 2 & Storage facilities & & & & & & & \\
\hline 2 & $\begin{array}{l}\text { High Cost of packing } \\
\text { and transportation } \\
\text { charges }\end{array}$ & 84 & 67.74 & 458 & 91.6 & 95.09 & 0.95 & II \\
\hline 3 & $\begin{array}{l}\text { Non availability of link } \\
\text { roads }\end{array}$ & 78 & 64.51 & 447 & 89.4 & 82.85 & 0.78 & III \\
\hline D & \multicolumn{3}{|c|}{ Problems related to marketing of carnation } & & & & & \\
\hline 1 & $\begin{array}{l}\text { Unavailability of local } \\
\text { market }\end{array}$ & 80 & 64.52 & 451 & 90.2 & 88.50 & 0.95 & IV \\
\hline 2 & $\begin{array}{l}\text { Lack of market } \\
\text { information }\end{array}$ & 100 & 80.64 & 493 & 98.6 & 115.14 & 0.64 & I \\
\hline 3 & Middle men & 96 & 77.42 & 481 & 96.2 & 106.17 & 0.64 & II \\
\hline 4 & Delayed payments & 90 & 72.58 & 464 & 92.8 & 98.14 & 0.58 & III \\
\hline 5 & Fluctuated prices & 90 & 72.58 & 464 & 92.8 & 98.49 & 0.60 & III \\
\hline
\end{tabular}


Table.3 Suggestions given by carnation growers

\begin{tabular}{|l|l|c|c|c|c|c|}
\hline S.No & Suggestions & $\begin{array}{c}\text { Weighted } \\
\text { score }\end{array}$ & Mean & $\begin{array}{c}\text { Standard } \\
\text { deviation }\end{array}$ & Skewness & Rank \\
\hline $\mathbf{1}$ & $\begin{array}{l}\text { Availability of quality planting material } \\
\text { from institutes }\end{array}$ & 433 & 86.6 & 77.12 & 0.57 & V \\
\hline $\mathbf{2}$ & Provide trainings to the farmers & 438 & 87.6 & 82.5 & 0.56 & IV \\
\hline $\mathbf{3}$ & Subsidized input materials & 453 & 90.6 & 90.13 & 0.74 & III \\
\hline $\mathbf{4}$ & $\begin{array}{l}\text { Timely and sufficient guidance with respect } \\
\text { to input availability, cost, arrival etc }\end{array}$ & 453 & 90.6 & 90.13 & 0.58 & III \\
\hline $\mathbf{5}$ & Better transportation facilities & 464 & 92.8 & 102.05 & 1.04 & II \\
\hline $\mathbf{6}$ & Provide credit on less interest & 422 & 84.4 & 67.33 & 0.36 & VI \\
\hline $\mathbf{7}$ & Establish local markets & 370 & 74 & 51.55 & 0.1 & VIII \\
\hline $\mathbf{8}$ & Less interference of middle men & 465 & 93 & 92.94 & 0.55 & I \\
\hline $\mathbf{9}$ & Timely payments by wholesaler, retailers & 374 & 74.8 & 59.66 & 1.2 & VII \\
\hline $\mathbf{1 0}$ & Fix the prices for product & 357 & 71.4 & 42.77 & 0.61 & IX \\
\hline
\end{tabular}

Problems related to storage, packing and transportation of carnation

Flowers are highly perishable in nature and to maintain its freshness, adequate storage facilities are required. Perishable nature of the produce was the most expressed (73.39 per cent) problem by the respondents and ranked as first. Another important process was packing of the produce and material used for packing should be chosen very carefully so that it can protect the flowers against stress during distant transportation. High cost of packing material and transportation charges was another major constraint faced by carnation growers with the mean value of 91.60 and assigned second rank, followed by absence of link roads from the place of produce to the main road (mean score of 89.4 and rank III).

\section{Problems related to marketing of carnation}

Market is the ultimate place for selling produce and marketing behaviour of the grower decides the economics of the business. Growers were having very little or no knowledge about the market trends, suitable marketing place for selling their produce and market demand and was a major constraint encountered by carnation growers with a mean score of 98.6 (rank I). Another issues expressed by respondents related to marketing of carnation were interference by middle men (mean score of 96.2 and rank II), delayed payments and fluctuated prices (mean score of 92.8 and rank III) and lack of local market assigned fourth rank with a mean score of 90.2 .

\section{Suggestions given by carnation growers}

Suggestions drawn from the farmers to lessen the frequency of problems encountered in the commercial cultivation of carnation are enumerated in Table 3. Examination of data revealed that majority of the respondents encountered problems regarding more participation of middle men in the marketing of carnation up till the final destination and hence proposal regarding less involvement of middle men assigned as first rank with a total mean score of 90. Suggestions were also given by the growers to improve the link roads and transport facilities (mean score of 92.8 and rank II) Easily accessible subsidies for the input materials and judicious guidance with respect to input availability, cost and 
arrival etc both were ranked third with a mean score of 90.13 , followed by growers demand for regular training programmes regarding demonstration of new technologies with a mean score of 87.6 acquired fourth rank. Availability of quality and planting material (mean score 86.6), credit at less interest (mean score of 84.4), timely payment by wholesalers cum commission agents (78.4) was ranked as fifth, sixth and seventh. Demand for the fixation of price with the least mean score (71.4) acquired ninth rank.

In conclusion, the state of Himachal Pradesh has bestowed with the favourable agroclimatic conditions which enables the production of variety of flowers in the state. It immense potential as far as the commercial cultivation of flowers is concerned. The Floriculture business in Himachal is still in its developing stage and requires lot of assistance and guidance from the Govt. for its expansion. The study was conducted in order to identify the constraints experienced by the carnation growers and assist various agencies to built farmer friendly policies. Lack of necessary market information, unavailability of skilled labour, high cost of inputs and unavailability of quality planting material were recognized as major constraints in the commercial cultivation of carnation. To overcome such issues and make floriculture more profitable it is necessary to provide basic facilities to the farmers whether financial or technical. Block level trainings should be conducted to spread awareness about the newly developed technologies and schemes amongst growers.

\section{References}

Anonymus, Annual Report, National Horticulture Board, Himachal Pradesh. 2019.

Ghadge S N, Chandgude D S and Jadhav M V. 2010. Constraints analysis and identification of strategies for the cut flower producers. Agriculture Update $5(1 \& 2)$ 177-180.

Raina V, Nain M S, Sharma R, Khajuria S, Kumbhare N V and Manish Bakshi. Floriculture in Jammu and Kashnir: Performance, problems and prospects.

\section{How to cite this article:}

Preeti Sharma, H. S. Baweja, K. K. Raina, B. S. Dilta, Y. C. Gupta and Pardeep Kumar. 2020. Problems and Constraints in the Production and Marketing of Carnation Cut Flowers in Himachal Pradesh. Int.J.Curr.Microbiol.App.Sci. 9(11): 3414-3419. doi: https://doi.org/10.20546/ijcmas.2020.911.407 